\title{
Human-Asian wild elephant (Elephas maximus) conflicts and its socio-economic consequences in and around the protected areas of Central Terai, Nepal
}

\begin{abstract}
B.R. Yadav ${ }^{1}$, I. C. Dutta ${ }^{2}$, M. K. Chalise ${ }^{3}$ and C. Williams ${ }^{4}$
The study was carried out in and around the two protected areas of Central Terai, Nepal with the primary aim of assessing the socio economic losses due to human-wild elephant conflicts. The field work was conducted during May 2010 to April 2011 through field observation, household survey, focus group discussion and key informant interviews. Loss of 50 houses and 15 lives were noticed during the study period in the study sites whereas five wild elephants were killed during 2005-2010. An estimated amount of about NRs. 2,000,000 (US\$25,165) was found as the economic loss due to crop raiding by elephants in Parsa District for the year 2009; whereas it was slightly less to a level of about NRs. 1,600,000 (US\$ 20,289) in the year 2010. However, the economic loss due to crop damage by wild elephants raiding in the Buffer Zone (BZ) of the Chitwan National Park (CNP) was nearly half of the Parsa District. The per household economic loss from crop damages were estimated to be around NRs 5,000 (US\$ 65.96) and NRS 6,135 (US\$ 77.67) in Parsa District and the BZ of the CNP respectively. About 1000 hectares of forestland have been found to be occupied by about 650 families in and around the buffer zone of the CNP and Parsa Wildlife Reserve (PWR). Compensatory relief for victimized families are the immediate solution in reducing the conflict whereas cultivation of unpalatable crops in and around the elephant routes as well as practice of agro-forestry are some of the long term solution in the habitat of wild elephants.
\end{abstract}

\section{Key words: Asian wild elephant, habitat encroachment, crop damage, human killings, elephant killings, Nepal}

1 sian elephant is the only living species of the genus Elephas and is distributed in Southeast Asia from India in the west to Borneo in the east. Since 1986, Elephas maximus has been listed as an endangered by IUCN since the population has declined by at least $50 \%$ over the past three generations (estimated to be 60-75 years). The species is pre-eminently threatened by habitat loss, degradation and fragmentation (Chalise, 2008; Williams, 2002; Yadav and Chalise, 2013; Hoare, 2000; Sukumar, 2006). At least one million human population and approximately 147-171 Asian wild elephants in Nepal are severely affected among each other (Yadav, 2002; Gopali, 2007; 2005; Pradhan, 2006; Yadav and Chalise, 2013).

Elephants were once distributed in low land Terai of Nepal. They were abundant in Central Part around the area that is now CNP (Oliver, 1978).
A total of wild and captive elephants are 353-385 surviving in and around the protected areas and in the captivity. A population of wild elephants estimated by Yadav (2002); Pradhan (2007), based on the personal communication with personnel of the Bardia NP (2011), and the PWR (2009); Petra (1999); Yadav and Chalise (2012) is 147-171 distributed in different geographical sub-populations: $12-13$ in Eastern, 40-50 in Central, 75-90 in Mid-western and 12-18 in Farwestern regions in Nepal. These wild elephants inhabit in a total forest area of $10,982 \mathrm{~km}^{2}$ and out of this total habitat, a $4,281.8 \mathrm{~km}^{2}$ areas are under the protected area in Nepal (DNPWC/ ECAP, 2009). In most places the mega herbivores are now compressed into protected areas which in general are too small for long term population persistent (Owen-Smith, 1988; Sukumar, 1989a).

Nepal is well recognized internationally for forest

Institute of Forestry, Pokhara Campus, Nepal, Email: yadav.baburam@gmail.com

${ }^{2}$ Tribhuwan University, Kathmandu, Nepal

${ }^{3}$ Central Department of Zoology, Tribhuvan University, Nepal

${ }^{4}$ AREA WWF International 
management. However, passive participation of community in decision making for the management of conservation areas has brought serious implication to the livelihood and cultural dynamics of the local people (McLean and Straede, 2003). Moreover, population pressure particularly the expansion of urban areas and agriculture, has caused conservation areas to become islands or increasingly fragmented habitats (Molnar, 2006). Existing provisions and arrangement deprived the people living outside the national parks and reserve from using forest products which they had been doing traditionally, much before the parks and reserves were created (Bhattrai et al., 2011; Dhungel and Adhikari, 1994 ).

The human exploited the elephant's habitat for a variety of plant resources such as fruits, barks, fodder, climbers, grasses firewood and timber (Sukumar, 1991). The growing human population collected the edible foodstuffs like wild bananas, wild bamboos, climbers and wild cassava from the habitat of elephants (Yadav, 2002; Yadav and Chalise, 2012 and 2013). One of the most serious case of human wildlife conflict is the fear of being killed by wildlife (Thirgood et al., 2005). Attitude of local people is vital in wildlife conservation and the attitude may vary according to gender, age, education and past experience with the particular species of wildlife (Hill, 1998; Røskaft et al., 2007). Matured and older people generally have more negative attitudes as do people who have experienced damage from wildlife while people with higher levels of education tends to be more positive towards wildlife (Røskaft et al., 2007). HEC occurs wherever people and elephant coincide, which is an obvious challenges for wild elephant conservation (Hoare, 2000; Sitati et al., 2003; Sukumar, 2006). The elephant population in Central Nepal has come in conflict with human relatively less than eastern population (DNPWC, 2009). This study concentrates in assessing the socio economic consequences of human-wild elephant conflicts in and around the protected areas of CNP and PWR (Yadav, 2005a, Yadav, 2005b, Yadav, 2005c, Yadav, 2005d).

\section{Materials and methods}

\section{Study Area}

The study area represents five districts (Chitwan, Parsa, Bara, Rautahat and Sarlahi) of Central Terai in Nepal. However, our field research was only concentrated in two districts (Chitwan and Parsa). Chitwan National Park (CNP) and Parsa Wildlife Reserve (PWR) cover a total area of $1,682 \mathrm{~km}^{2}$ and $797.17 \mathrm{~km}^{2}$ including buffer zone respectively. CNP the first protected areas of Nepal, was declared in 1973 and designated as UNESCO world heritage site in 1984. PWR was declared in 1984 with the aim of preserving the population of residential Asian wild elephants (E. maximus). The CNP core areas is located between $27^{\circ} 34^{\prime} 23^{\prime \prime} \mathrm{N}$ to $27^{\circ} 68^{\prime} 98^{\prime \prime} \mathrm{N}$ latitude and $83^{\circ} 87^{\prime} 79^{\prime \prime}$ E to $84^{\circ} 74 ' 30^{\prime \prime} \mathrm{E}$ longitude and the geographical location of the buffer zone of the CNP is located between $27^{\circ} 28^{\prime} 23^{\prime \prime} \mathrm{N}$ to $27^{\circ} 70^{\prime} 38^{\prime \prime} \mathrm{N}$ latitude and $83^{\circ} 83^{\prime} 98^{\prime \prime} \mathrm{E}$ to $84^{\circ} 77^{\prime} 38^{\prime \prime}$ 'E longitude (Fig. 1). PWR is located within $27^{\circ} 15^{\prime} \mathrm{N}$ to $27^{\circ} 33^{\prime} \mathrm{N}$ latitude and $84^{\circ} 41^{\prime} \mathrm{E}$ to $84^{\circ} 58^{\prime} \mathrm{E}$ longitude (Fig. 1). The temperature perceived was of $50^{\circ} \mathrm{C}$ in winter and $40^{\circ} \mathrm{C}$ in summer season. The rainfall in the eastern section gets on an average of $170 \mathrm{~cm}$ whereas the central section receives $150 \mathrm{~cm}$ annually.
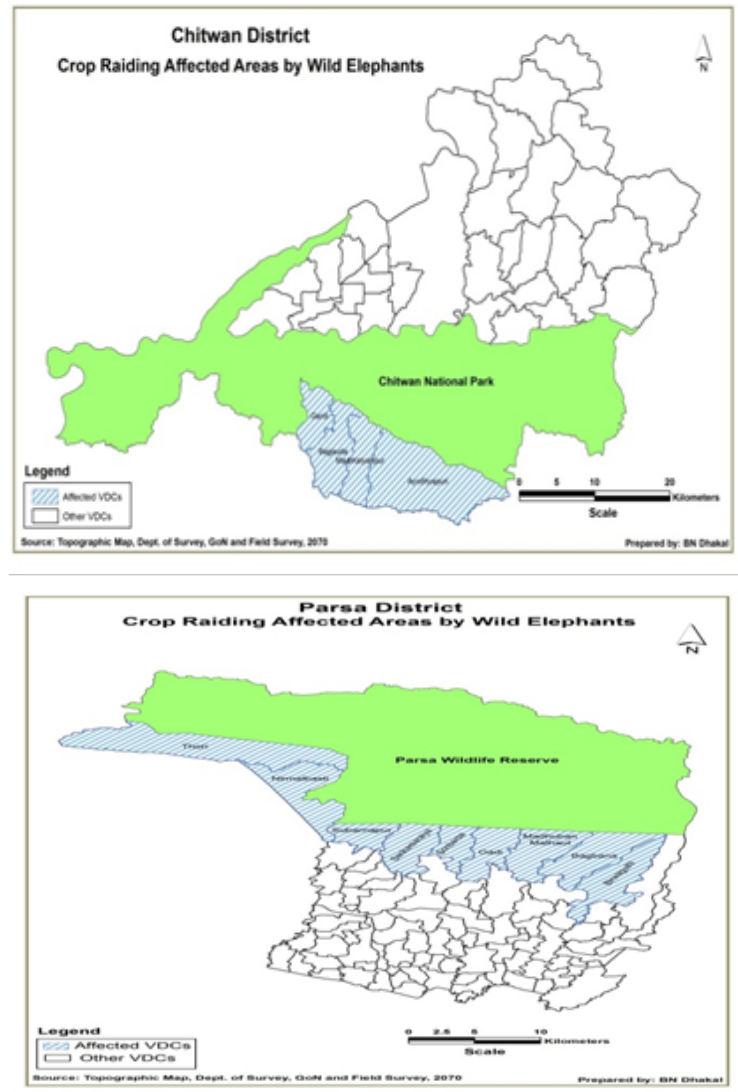

Fig. 1: Location of the study area

The purposive sampling was adopted for this study. Individual households, settlements and wards of the Village Development Committees (VDCs) were considered as the sampling units 
for different cases. The study team made inquiries with villagers to find out the affected households by wild elephants raiding. Most of the affected areas in and around the buffer zone of the PWR and the CNP were selected for the study. We further visited and collected data at the affected sites in wards, settlements and cultivated land. Affected VDCs of Parsa District both in and around the buffer zone as well as affected VDCs in Chitwan District around the buffer zone of CNP were selected for data collection. The direct field observation and measurement of the sites were done to get information on crop damage by wild elephants. Most of the affected sites were visited and recorded for crop damage as well as indirect sign of elephant's foot prints and dung.

Crop raiding was monitored in 13 VDCs of two districts- Chitwan $(n=4)$ and Parsa $(n=9)$. Crop depredation by elephants were monitored following a standardized data collection protocol (Hoare, 1999) and modified to avoid the problem of exaggeration by farmers (Tchamba, 1996; Hedges et al., 2005). The collected data included date, location characteristic of damage and size class, sex and social grouping of elephant's involved.

\section{Results and discussion}

\section{Economic loss in Buffer Zone of Chitwan National Park}

During 12 months of the study period 105 incidents of crop damage were recorded around the CNP. Most of such incidents were found to have occurred between May 2010 and April 2011 due to persistent groups of raiding elephants. Four VDCs, (Ayodhyapuri, Bagauda, Gardi and Klayanpur) of Chitwan District were found to be most affected areas. Out of these VDCs Bagauda VDC had severe damage and Gardi had little damage (Table 1).
A total of 30.4 hectares farmland was affected by elephants raiding. The elephants raided the different crops equivalent to about NRs. 1,000,000 (US\$ 12,791.77) in 2010, while a total crops damage raided by elephant equivalent to about NRs 547,000 (US\$ 69,125.95) in 2009. Table 1 indicates that the damage by wild elephants raiding is increasing annually in the settlements, wards and VDCs of the buffer zone of CNP. The crops damage by elephants raiding in 2010 was about double of the damaged occurred in 2009. Affected areas are surrounded by forest land. These VDCs are prone to wildlife damage and human casualties /injured by wild elephants.

\section{Damage in Buffer Zone of Chitwan National Park by crops}

Five types of crops (rice, wheat, maize, lentil and banana) were raided by wild elephants in the buffer zone of CNP. The damage was estimated at around about NRs. 497,000 (US\$ 6,292) for rice, about NRs. 34,000 (US\$ 444) for maize and NRs. 15,000 (US\$ 190) for wheat for the year 2009. Whereas, the damage was about NRs.784,300 (US\$ 9,928) for rice, about NRs 136,000 (US\$ 1,178) for wheat and NRs. 45,000 (US\$ 479) for maize in 2010. Figures 2 and 3 show that depredation was very high in rice crop both in 2009 and 2010. The results indicate that the rice is more preferable to wild elephant than wheat and maize.

\section{Economic loss by elephants raiding in Parsa District}

A total of 116.42 hectares of crops were raided by wild elephants in nine VDCs of Parsa District Crops damage by wild elephants raiding in Parsa District was estimated to be around about NRs. 1,600,000 (US\$ 20,228.86) and about NRs. 2,000,000 (US\$ 25,164.68) in 2010 and 2009 respectively. Severe damage was found in

Table 1: Crops depredation in the BufferZone of CNP

\begin{tabular}{|c|c|c|c|c|c|c|c|c|}
\hline \multirow[b]{2}{*}{ VDCs } & \multicolumn{4}{|c|}{ Year 2009} & \multicolumn{4}{|c|}{ Year 2010} \\
\hline & $\begin{array}{c}\text { Affected } \\
\text { Area (ha) }\end{array}$ & $\begin{array}{c}\text { Investment } \\
\text { (NRs.) }\end{array}$ & $\begin{array}{l}\text { Production } \\
\text { (NRs.) }\end{array}$ & $\begin{array}{c}\text { Damage } \\
\text { (NRs.) }\end{array}$ & $\begin{array}{c}\text { Affected } \\
\text { Areas (ha) }\end{array}$ & $\begin{array}{l}\text { Investment } \\
\text { (NRs.) }\end{array}$ & $\begin{array}{l}\text { Production } \\
\text { (NRs.) }\end{array}$ & $\begin{array}{c}\text { Damage } \\
\text { (NRs.) }\end{array}$ \\
\hline Ayodhyapuri & 4.7 & 83,000 & 271,450 & 190,000 & 6 & 105,400 & 318,650 & 268,500 \\
\hline Bagauda & 3.8 & 46,700 & 326,000 & 248,000 & 8.2 & 130,900 & 591,000 & 455,750 \\
\hline Gardi & 0.9 & 12,300 & 53,450 & 27,000 & 3.6 & 58,000 & 220,700 & 191,800 \\
\hline Kalayanpur & 1.4 & 22,500 & 99,150 & 82,150 & 1.9 & 28,500 & 137,500 & 94,500 \\
\hline Total & 10.7 & 164,500 & 750,050 & 547,150 & 19.7 & 322,800 & $1,267,850$ & $1,010,550$ \\
\hline
\end{tabular}

Sources: Field work, 2010 (Currency NRs. $79=1$ US\$) 


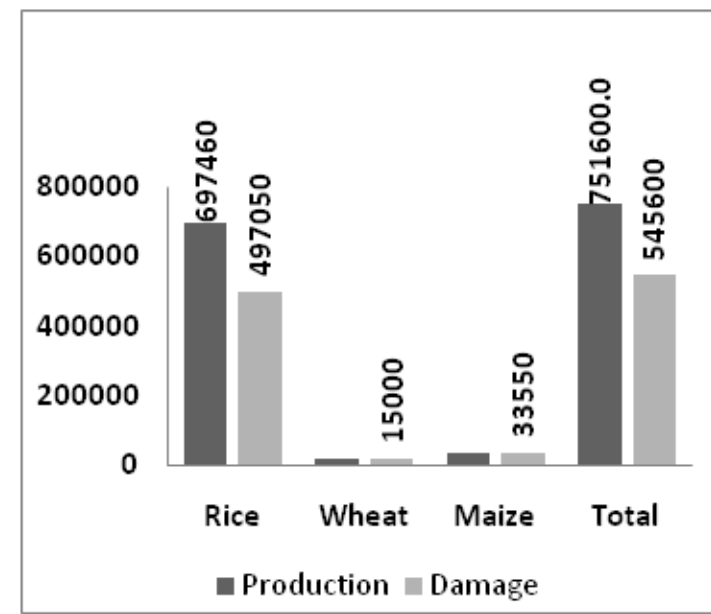

Fig. 2: Crop wise economic loss

(NRs.) in Chitwan district 2009



Fig. 3: Crop wise economic loss (NRs.) in Chitwan district 2010

Table 2: Crops depredation in Parsa District

\begin{tabular}{|c|c|c|c|c|c|c|c|c|}
\hline \multirow[b]{2}{*}{ VDCs } & \multicolumn{4}{|c|}{ Year 2009} & \multicolumn{4}{|c|}{ Year 2010} \\
\hline & $\begin{array}{c}\text { Affected } \\
\text { Areas (ha) }\end{array}$ & $\begin{array}{c}\text { Investment } \\
\text { (NRs.) }\end{array}$ & $\begin{array}{l}\text { Production } \\
\text { (NRs.) }\end{array}$ & $\begin{array}{l}\text { Damage } \\
\text { (NRs.) }\end{array}$ & $\begin{array}{c}\text { Affected } \\
\text { Area (ha) }\end{array}$ & $\begin{array}{l}\text { Investment } \\
\text { (NRs.) }\end{array}$ & $\begin{array}{l}\text { Production } \\
\text { (NRs.) }\end{array}$ & $\begin{array}{c}\text { Damage } \\
\text { (NRs.) }\end{array}$ \\
\hline Sonbarsa & 6.93 & 319,104 & $570,435.48$ & 252,400 & 11.51 & $412,025.71$ & $728,600.24$ & 441,400 \\
\hline Subarnpur & 16.40 & 223,600 & 903,800 & 350,660 & 3.23 & $157,418.41$ & $283,271.04$ & 148,700 \\
\hline Nirmalbasti & 5.83 & $284,002.28$ & 511,056 & 349,800 & 2.43 & $118,469.52$ & $213,183.36$ & 71,800 \\
\hline Gadi & 8.10 & 369,754 & $660,316.64$ & 261,300 & 9.55 & $404,211.55$ & $714,910.56$ & 344,219 \\
\hline M.Mathwal & 13.23 & 156,260 & $881,761.6$ & 242,000 & 13.27 & 139,800 & 518,100 & 353,500 \\
\hline S.Saraiya & 2.97 & $144,435.44$ & $259,908.48$ & 60,700 & 0.93 & $45,440.364$ & $81,768.96$ & 30,000 \\
\hline Biruwaguthi & 2.53 & $123,338.13$ & $221,944.32$ & 105,650 & 0.80 & $38,948.884$ & $70,087.68$ & 30,000 \\
\hline Bagbana & 6.53 & $294,165.15$ & $527,766.72$ & 175,100 & 1.07 & $48,087.494$ & $85,743.84$ & 15,500 \\
\hline Thori & 6.60 & $313,825.19$ & $570,719.76$ & 190,400 & 4.50 & $216,451.25$ & $395,277.48$ & 167,700 \\
\hline Grand total & 69.13 & $2,228,484$ & $5,107,709$ & $1,988,010$ & 47.29 & $1,580,853$ & $3,090,943$ & $1,602,819$ \\
\hline
\end{tabular}

Sources: Field work, 2010 (1 US\$ = NRs. 79)

Sonbarsa (US\$ 5,527.34), Madhuvan Mathawal (US\$ 4,474.68) and Gadi VDCs (US\$ 4,357.2) in 2010 (Table 2). These VDCs are contiguous to the national forest and the national forest of Parsa District is contiguous to the PWR.

\section{Economic loss in Parsa District by crops}

Rice, maize, wheat and lentil cereal crops were raided by wild elephants in Parsa District. Rice damage was found to be higher in both years that were about NRs. 1,900,000 (US\$ 24,171) for the year 2009 and about NRs. 1,019,000 (US\$ 12,896.4) in 2010 in nine VDCs of Parsa District. The rice damage was followed by the wheat crops in both years (Fig. 4).
Economic loss from crop damages in Parsa District

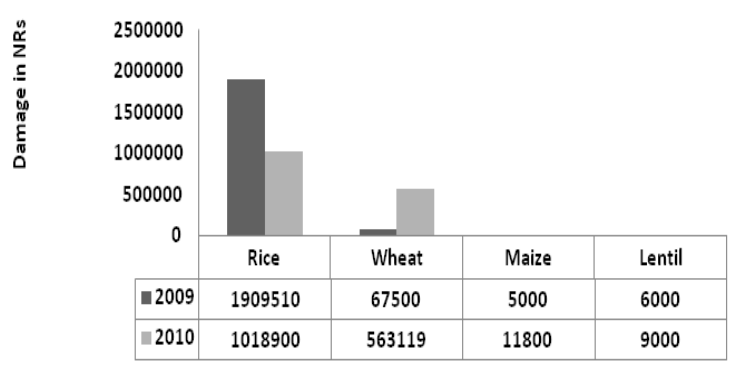

Fig. 4: Economic loss by crop damages in Parsa District

\section{Comparison of economic loss between Chitwan and Parsa Districts}

Table 3 indicates that the crop damages in Chitwan and Parsa Districts are in different trend. 
Economic loss due to elephants raiding in Chitwan looks much lesser than that of economic loss in Parsa District in 2009 and 2010. The losses cover four VDCs in the buffer zone of the CNP while losses cover nine VDCs inside BZ and outside the BZ in Parsa District. The economic loss in Chitwan District was found to be in increasing trend (NRs.547,000-1,011,000) while economic loss in Parsa was found to be in decreasing trend (NRs. 2,000,000-1,600,000).
The table 4 indicates that the surplus amount per HHs was estimated to be NRs. 1,900 (US\$ 24.46) and NRs. 9,600 (US\$ 121.88) in Chitwan and Parsa Districts respectively. The estimated surplus amount could not fulfill the daily demand of food supply for the affected people. The result showed that the people living in the vicinity the PWR and the CNP were severely affected by elephants raiding of crops. On the other hand, the wild elephants were found to be also

Table 3: Food deficit in the affected areas around the CNP and PWR

\begin{tabular}{lrrrrrrr}
\hline \multirow{2}{*}{ District } & \multicolumn{3}{c}{ Year 2009 } & & & Year 2010 & \multicolumn{2}{c}{ Remark } \\
\cline { 2 - 8 } & TP(NRs.) & TD (NRs.) & TS & TP (NRs.) & TD (NRs.) & TS & $\begin{array}{c}\text { Affected } \\
\text { HH }\end{array}$ \\
\cline { 2 - 8 } & 750,050 & 547,150 & 202,900 & $1,267,850$ & $1,010,550$ & 257,300 & 105 \\
PHITWAN & $5,107,709$ & $1,988,010$ & $3,119,699$ & $3,090,943$ & $1,602,819$ & $1,488,124$ & 324 \\
Grand Total & $5,857,759$ & $2,535,160$ & $3,322,599$ & $4,358,793$ & $2,613,369$ & $1,745,424$ & 429 \\
Grand Total US\$ & $74,148.85$ & $32,090.63$ & $42,058.22$ & $55,174.59$ & $33,080.62$ & $22,093.97$ & \\
\hline
\end{tabular}

Total Production (TP), Total Damage (TD), Total Surplus (TS); 1US\$ =NRs. 79

The table 3 also indicated that the total estimated crop production (US\$74,148.5) was more than the total damage of crops (US\$ 32,090.63) in 2009. Likewise the total production of crops was more than total damage (US\$33,080.62) in 2010. The estimated total surplus value of crops was found to be US\$ 42,058.22 in 2009, while the estimated total surplus productions of the crops in 2010 was found equivalent to US\$22,093.97. These results showed that the total production was greater than the total damage, but the remaining income was not sufficient for a person for the whole year.

Altogether 429 households were found to have been affected elephants' raiding in Parsa and Chitwan Districts. The economic loss due to crop damage per HHS by wild elephants raiding were estimated to be about NRs 5,000 (US\$ 65.96) and NRs. 6,000 (US\$ 77.67) in Chitwan and Parsa Districts respectively. victimized by the local people. Sometimes the local people killed the wild elephants using shot gun, and by poisoning and through electrocution. The victimized people were found to be having suffered from the problems of compensation.

\section{Human casualty and Elephants Mortality}

Twenty five houses were demolished and 15 persons were killed in the buffer zone of PWR and CNP in the two districts whereas four elephants were killed during the study period. Human casualty is increasing annually in Central Nepal by wild elephants. Mostly the male elephants killed the human during guarding their crops and properties. Elephant mortality is also very high in Nepal. Five wild elephants have killed out of 22 wild elephants within 2004-2009 in Central Nepal. A total of 52 wild elephants have been dead (Natural and retaliatory) during 1994-July 2013.

Table 4: Surplus per household in Chitwan and Parsa Districts

\begin{tabular}{|c|c|c|c|c|}
\hline District & $\begin{array}{c}\text { Surplus /HHS NRs. } \\
\text { Annually }\end{array}$ & $\begin{array}{l}\text { Per person (Family size } \\
\text { 5.5)/Annually surplus }\end{array}$ & $\begin{array}{l}\text { Per person per } \\
\text { month }\end{array}$ & $\begin{array}{l}\text { Needed per person annually } \\
\text { at least for livelihood NRs }\end{array}$ \\
\hline Chitwan & $\begin{array}{r}1,932.38 \\
(\mathrm{US} \$ 24.46)\end{array}$ & $\begin{array}{r}351.34 \\
(\mathrm{US} \$ 4.44)\end{array}$ & $\begin{array}{r}29.27 \\
(\mathrm{US} \$ 0.37)\end{array}$ & 72,000 (US\$ 911.39) \\
\hline Parsa & $\begin{array}{r}9,628.70 \\
(U S \$ 121.88)\end{array}$ & $\begin{array}{r}1,750.67 \\
(\mathrm{US} \$ 21.16)\end{array}$ & $\begin{array}{r}58.35 \\
(\mathrm{USS} 0.74)\end{array}$ & 72,000 (US\$ 911.39) \\
\hline
\end{tabular}

Note: If a person spends NRs. 200 for food per day they need NRs.72,000/year 


\section{Crops seasons and damage}

The crop damage by wild elephant in Nepal follows a seasonal pattern with two peak seasons of crop damage (June-July), during maize and wheat maturing period and September-November during rice maturing time (Pradhan et al., 2011). Rice is the major crop in the Terai region of Nepal. Generally, rice farming is in two seasons i.e., summer and winter, where there the irrigation is available whole year. A similar crops raiding was observed in India where crops damage take place during June to August and October to November, two peak seasons for two types of rice, on cultivated in shallow water and the other in deep water levels (Lahkar et al., 2007). Yadav (2002) investigated crop damage in Eastern Nepal by wild elephants that people are severely affected by loss of crops and their life. He also mentioned there is very limited habitat for wild elephants that's why the damage is higher in Eastern Nepal.

\section{Habitat fragmentation}

Many settlements have been occupied the biological corridors habitat of Asian wild elephants by migrating people and the current increasing human population. National and International biological corridors of wild elephants have been encroached by about 570 households were in the core and buffer zone of the CNP and the PWR. About 500 hectares of forestland encroached by the people in the BZ of CNP at Ayodhyapuri VDC-9, Bandarjhulla settlement. Similarly about 324 hectares of forestland which is international corridors among PWR, CNP and Balmiki Tiger Reserve in Nirmalbasti VDC of Parsa District has been encroached by about 100 families. 20-25 families have been living in Hadikhola VDCs at Bhiman. A total of about 1000 hectares (Bandarjhulla, Nirmalbasti and Bhimanchuria areas) of forest lands are occupied by the people. About 2000 people in Bandarjhulla, 500 people in Nirmalbasti (Syaulibazar) and 100-150 people are living illegally in these areas (CNP and PWR offices, 2010).

\section{Exaggerate damage records in Parsa District}

The quantities of the crop damaged records were found in some VDCs seem as exaggerate in 2009 compared to the crop damage in 2010 in Parsa District. The estimated damage in 2009 was US\$ 25,165 (NRs. $79=1$ US\$) whereas the crop damage estimated in 2010 was US\$ 20,229. In the case of Chitwan District the trend of crop damage is in increasing order e.g. damage in 2009 was US\$ 6,926 whereas the damage in 2010 was US\$ 12,792. In the case of Parsa District, respondents might not have provided real damage records to studyteam for 2009, as they might have expected that whatever damage might be compensated by the government. On the other hand the study team might not have clearly explained about the objectives of the research to the respondents during the data collection period in some VDCs.

\section{Conclusion}

Forty to fifty Asian wild elephants were reported to be harboring in Central Development Region of Nepal during the study period. Now the wild elephant's population is facing severe problems due to habitat fragmentation in the Central Terai of Nepal. Remaining habitat has been also used by the local people for their cattle grazing and collection of fodder and grasses. Unscientific exploitation of their habitat has created scarcity of forage for the wild elephants. Insufficient forage in the forest compels the elephants to raid the crops in settlements surrounding the habitat. The above activities done by local people and elephants create human-elephant conflict.

The poor people living near the elephant's habitats are severely affected by elephants raiding and demolishing their huts annually. Sometimes the elephants were found to be having killed/ injured the local people guarding their crops in their conventional thatched-watching huts.At the same time the affected farmers had also killed the wild elephants through poisoning, using shut gun and through electrocution. Government of Nepal enforced the Relief Guidelines, 2010 amended in 2013 to compensate for human casualties and crop damage which are not sufficient to motivate them towards conservation of Asian wild elephants. Edible and palatable crops preferred by elephants should be discouraged in the cultivation of problematic areas. Simultaneously the government should manage the palatable agricultural crops like sugarcane, bananas maize and plenty of fodder trees inside the habitat of elephants.

\section{References}

Chalise, M. K. 2008. Nepalka Samrakshit Banyajantu, (Nepal's Protected Wildlife 
in Nepali). Shajha Prakashan, (A Corporate publishing house) Lalitpur, Kathmandu Nepal.

Dhungel, S. and Adhikari, B. 1994. Buffer zone Vital Minimize People Park Conflict. In Kathmandu Post National Daily Newspaper, Kathmandu, Nepal. October 30, 1994.

DNPWC. 2009. The Elephant Conservation Action Plan of Nepal. Department of National Parks and Wildlife Conservation, Kathmandu, Nepal.

DNPWC. 2012. Chitwan National Parks and Buffer Zone Management Plan 2012-2016 (Final Draft). Department of National Parks and Wildlife Conservation, Kathmandu, Nepal.

Hedges, S., Tyson, M. J., Sitompul, A. F., Kinnaird, M. F., Gunaryadi, D. and Aslan. 2005. Distribution, status and conservation needs of Asian elephants (Elephas maximus) in Lampung province, Sumatra Indonesia. Biological Conservation 124 (1): 35-48.

Hill, C. M. 1988. Conflict attitude towards elephants around the Budongo Forest, Reserve Uganda. Environmental Conservation 25 (3): 244-250.

Hoare, R. E. 2000. African elephants and human in conflict: the outlook for co-existence. Oryx 34: 34-38.

McLean, J. and Strede, S. 2003. Conservation, Relocation and Paradigms and Park and People Management. A case study of Padampur Village. Royal Chitwan National Park, Chitwan, Nepal.

Pradhan, N. M. B., Williams, A. C. and Dhakal, M. 2011. Current status of Asian elephants in Nepal. Gajah 30: 41-52.

Røskaft, E., Handel, B., Bjerke, T. and Kaltenborn, B. P. 2007. Human attitudes towards large carnivores in Norway. Wildlife Biology 13: 172-185.

Sitati, A. W., Walpole, M. J., Smith, R. J. and Leader-Williams, N. 2003. Predicting spatial aspects of human-elephant conflict. Journal of Applied Ecology 40: 667-677.
Sukumar, R. 1991. The Management of large mammals in relation to male strategies and conflict with people. Biological Conservation 55: 93-102.

Sukumar, R. 2006. A brief review of the status, distribution and biology of wild Asian elephants Elephas maximus. International Zoo Yearbook 40: 1-8.

Tchamba, M. N. 1996. History and present status of the human/elephant conflict in the WazaLogone region, Cameroon, West Africa. Biological Conservation 75: 35-41.

Thirgood, S., Woodroffe, R. and Rabinowitz, A. 2005. The Impact of Human-Wildlife Conflict on Human Lives and Livelihoods. Conservation Biology Series Cambridge-9, 13.

Williams, A. C. 2002. Elephants (Elephas maximus), and their Habitats in Rajaji-Corbet National Park, Northwest India. A thesis for the Degree of Doctor of Philosophy in Wildlife Science, Saurashtra University Rajkot, India.

Yadav, B. R. and Chalise, M. K. 2013. Nepalma Jangali Hatti ra Manis Bicha Dwanda (Conflict between elephant and human in Nepal). 18 $8^{\text {th }}$ Wildlife Week, 2070 BS. DNPWC/Govt. of Nepal.

Yadav, B. R. and Chalise, M. K. 2012. Jangali Hatti ra manis tatha dwanda (Wild Elephant and human and conflicts). World Environment Day June 05. Hamro Sampada 12 (1): 84-89.

Yadav, B. R. 2005a. Asian Wild Elephant-Human Conflicts and Measures to Reduce the Damage due to Elephants in Eastern Nepal. $10^{\text {th }}$ wildlife week. Department of National Park and Wildlife Conservation, Babarmahal Kathmandu, Nepal.

Yadav, B. R. 2005b. Assessment of crop damage by Asian wild elephants in Jhapa district Eastern Nepal. Banko Janakari 13 (1): 5056.

Yadav, B. R. 2005b. Asian wild elephant (Elephas maximus) in eastern Nepal. The Journal of Forestry 12 (3): 68-81. 
Yadav, B. R. 2005d. "Human-Elephant Relationship and Conflicts in Eastern Nepal", Endangered Elephants, past, present and future. Proceedings of the Symposium for Human-Elephant Relationships and Conflicts Sri-Lanka, Colombo, August 2005, 90-92.
Yadav, B. R. 2002. Elephant (Elephas maximus) People Interface in East Nepal. M.Sc. Thesis, Agricultural University of Norway, Norway.

Yadav, G. 2007. Human-Elephant relationships and in Eastern Nepal. Environment Conservation 1 (1): 93-99. 